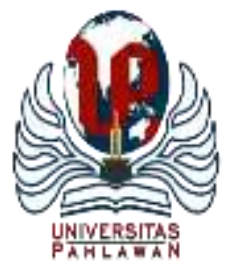

Edukatif : Jurnal Ilmu Pendidikan Volume 4 Nomor 1 Tahun 2022 Halm 123 - 132

EDUKATIF: JURNAL ILMU PENDIDIKAN

Research \& Learning in Education

https://edukatif.org/index.php/edukatif/index

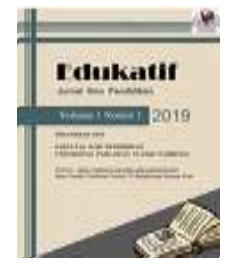

\title{
Pengembangan Instrumen Penilaian Berbasis Higher Order Thinking Skills pada Mata Pelajaran Ekonomi Sekolah Menengah Atas
}

\author{
Ike Nur Sholiha ${ }^{1 凶}$, Riza Yonisa Kurniawan ${ }^{2}$ \\ Universitas Negeri Surabaya, Indonesia ${ }^{1,2}$ \\ E-mail : ikenursholiha@gmail.com ${ }^{1}$, rizakurniawan@ unesa.ac.id $^{2}$
}

\begin{abstract}
Abstrak
Ranah kognitif HOTS (Higher Order Thinking Skills) belum sepenuhnya diterapkan pada latihan soal dan instrumen penilaian, sehingga peserta didik mengalami kesulitan dalam mengerjakan soal level HOTS. Penelitian ini bertujuan untuk mengetahui proses pengembangan instrumen penilaian berbasis HOTS mata pelajaran ekonomi SMA kelas $\mathrm{X}$, mengetahui kualitas instrumen penilaian, serta mengukur kemampuan berpikir tingkat tinggi peserta didik yang dinilai dari hasil pengerjaan instrumen penilaian. Jenis penelitian adalah Research and Development (R\&D). Penelitian ini menerapkan metode pengembangan 3D yang merupakan modifikasi dari metode pengembangan. Hasil penelitian memperoleh 18 butir soal valid dan 2 butir soal tidak valid. Reliabilitas instrumen penilaian berbasis HOTS ini termasuk dalam kriteria tinggi. Instrumen penilaian ini memiliki rata-rata tingkat kesukaran soal dalam kategori sedang. Rata-rata daya pembeda soal pada instrumen penilaian ini dalam kategori sedang. Namun berdasarkan hasil penelitian ini menunjukkan bahwa rata-rata kemampuan berpikir tingkat tinggi yang dimiliki oleh peserta didik kelas X IPS SMA Negeri 1 Gedangan termasuk dalam kriteria kurang.
\end{abstract}

Kata Kunci: Instrumen Penilaian, Kemampuan Berpikir Tingkat Tinggi, Mata Pelajaran Ekonomi

\begin{abstract}
The cognitive domain of HOTS (Higher Order Thinking Skills) has not been fully applied to practice questions and assessment instruments, so that students have difficulty working on HOTS level questions. This study aims to determine the process of developing a HOTS-based assessment instrument for economic subjects in high school class $X$, to determine the quality of the assessment instrument, and to measure the students' higher-order thinking skills assessed from the results of the assessment instrument. The type of research is Research and Development $(R \& D)$. This research applies the $3 D$ development method which is a modification of the development method. The results of the study obtained 18 valid items and 2 invalid items. The reliability of this HOTS-based assessment instrument is included in the high criteria. This assessment instrument has an average level of difficulty in the medium category. The average discriminatory power of the questions on this assessment instrument is in the medium category. However, based on the results of this study, it shows that the average high-level thinking ability possessed by students of class X Social Sciences at SMA Negeri 1 Gedangan is included in the criteria for being lacking.
\end{abstract}

Keywords: Assessment Instruments, Higher Order Thinking Skills, Economics Subjects

Copyright (c) 2022 Ike Nur Sholiha, Riza Yonisa Kurniawan

$\triangle$ Corresponding author

Email : ikenursholiha@gmail.com

DOI : https://doi.org/10.31004/edukatif.v4i1.1736

ISSN 2656-8063 (Media Cetak)

ISSN 2656-8071 (Media Online)

Edukatif : Jurnal Ilmu Pendidikan Vol 4 No 1 Tahun 2022 p-ISSN 2656-8063 e-ISSN 2656-8071 
124 Pengembangan Instrumen Penilaian Berbasis Higher Order Thinking Skills pada Mata Pelajaran Ekonomi Sekolah Menengah Atas - Ike Nur Sholiha, Riza Yonisa Kurniawan

DOI: https://doi.org/10.31004/edukatif.v4i1.1736

\section{PENDAHULUAN}

Pendidikan memiliki peran dalam kehidupan masyarakat. Menurut Richey (1973) (dalam Anwar, 2015) peran pendidikan sebagai suatu aktivitas sosial dimana membenahi perkembangan kehidupan masyarakat, mengenal rasa tanggung jawab dalam bekerja sama. Pendidikan merupakan suatu kegiatan dalam membangun kepribadian seseorang, menumbuhkan bakat dan minat yang dimiliki serta dikembangkan pada lingkungan sosial agar terciptanya kehidupan yang sejahtera. Kualitas pendidikan di suatu negara perlu disorot, diharapkan generasi penerus dapat menumbuhkan daya saing serta dapat menambah SDM yang mumpuni melalui pendidikan.

Organization for Economic Co-operation and Development mengumumkan hasil Programme for Internasional Student Assessment (PISA) dari 77 negara. Hasil PISA Indonesia pada tahun 2018 mengalami kemerosotan dibandingkan dengan hasil PISA tahun 2015 (Anggraena, 2019). Perbandingan hasil PISA Indonesia tahun 2015 dan 2018 terdapat pada nilai kemampuan membaca yang semula 397 poin turun menjadi 371 poin, nilai kemampuan matematika yang semula 386 poin turun menjadi 379 poin, serta nilai kemampuan sains yang semula 403 poin turun menjadi 396 poin. Indonesia menduduki posisi ke 72 berdasarkan hasil PISA tahun 2018 dari 77 negara. Demikian pemerintah dapat melakukan perbaikan serta perubahan kualitas pendidikan nasional melalui pembelajaran.

Dalam pembelajaran, kurikulum merupakan suatu rencana pelaksanaan pendidikan yang akan diberikan kepada peserta didik. Ilmu pengetahuan dan teknologi mengalami perkembangan begitu cepat sehingga mempengaruhi segala aspek kehidupan, terutama di bidang pendidikan. Maka pemerintah Indonesia telah mengganti dan memperbarui kurikulum pendidikan dari masa ke masa. Pada saat ini, Indonesia menerapkan Kurikulum 2013 Revisi yang mulai diterapkan sejak tahun ajaran 2017/2018. Kurikulum 2013 Revisi menjadi bentuk perbaikan kurikulum berbasis karakter serta kompetensi.

Pada Kurikulum 2013 Revisi terdapat empat hal penting yakni Penguatan Pendidikan Karakter (PPK), Literasi, Keterampilan Abad ke-21 (4C) dan Higher Order Thinking Skills (HOTS) maka pendidik yang berperan sebagai fasilitator dalam pembelajaran dapat mengkombinasikan empat hal tersebut (Darise, 2019). Kemampuan keterampilan 4C yang terdiri dari komunikasi (Communication), kerjasama (Collaboration), berpikir kritis dan penyelesaian masalah (Critical Thinking and Problem Solving), serta kreativitas dan inovasi (Creativity and Innovation) merupakan jenis softskill yang diperuntukkan kepada setiap orang dalam menghadapi kehidupan di lingkungan masyarakat abad 21 dimana perkembangan dan inovasi teknologi menjadi faktor dalam perubahan pada kehidupan bermasyarakat (Arnyana, 2019). Berikutnya Higher Order Thinking Skills (HOTS) atau kemampuan berpikir tingkat tinggi yang semestinya dimiliki oleh peserta didik.

Berpikir tingkat tinggi ialah suatu proses berpikir kritis dan berpikir kreatif seseorang dalam penerimaan informasi, pengambilan keputusan serta penyelesaian suatu masalah (Fanani, 2018). Kemampuan berpikir tingkat tinggi sebagai cara berpikir peserta didik memperoleh suatu pengetahuan dan tersimpan dalam ingatannya, lalu pengetahuan tersebut diorganisasikan atau dievaluasi untuk mencapai suatu tujuan (Abosalem, 2016). Kemampuan berpikir tingkat tinggi yaitu kemampuan dalam menghubungkan antara pengetahuan yang dimiliki dan fakta yang ada kemudian memanipulasi sehingga memperoleh solusi dari suatu permasalahan (Nursalam et al., 2018). HOTS merupakan bekal peserta didik mempersiapkan diri untuk mengatasi tantangan persaingan global dengan perkembangan yang begitu pesat. Peserta didik selain memiliki pengetahuan yang tersimpan dalam memorinya namun juga mampu mengembangkan keterampilan serta menerapkannya dalam kehidupan bermasyarakat.

Dalam pelaksanaannya, peserta didik menghadapi kesulitan dalam berpikir tingkat tinggi seperti mengerjakan soal dengan level kognitif HOTS. Berdasarkan penelitian (Akmala et al., 2019) yang berjudul "Analisis Kemampuan Berpikir Tingkat Tinggi Siswa SMA pada Materi Hukum Newton Tentang Gerak" bahwa instrumen penilaian yang diuji cobakan dalam bentuk 20 butir soal pilihan jamak dengan materi 
125 Pengembangan Instrumen Penilaian Berbasis Higher Order Thinking Skills pada Mata Pelajaran Ekonomi Sekolah Menengah Atas - Ike Nur Sholiha, Riza Yonisa Kurniawan

DOI: https://doi.org/10.31004/edukatif.v4i1.1736

Hukum Newton tentang gerak. Subjek uji coba penelitian ini merupakan 456 peserta didik kelas X dari 5 Sekolah Menengah Pertama yang merupakan perwakilan dari masing-masing bagian Kota Bandar Lampung. Hasil penelitian tersebut menyatakan terdapat 7 peserta didik (1\%) dalam kriteria sangat tinggi, 21 peserta didik (5\%) dalam kriteria tinggi, 81 peserta didik (18\%) dalam kriteria cukup tinggi, dan terdapat 347 peserta didik $(76 \%)$ dalam kriteria rendah. Rata-rata kemampuan berpikir tingkat tinggi peserta didik pada penelitian tersebut dalam kategori rendah.

Menurut penelitian lain (Kurniawan \& Lestari, 2019) dengan judul "The Development Assessment Instruments of Higher Order Thinking Skills on Economic Subject" bahwa hasil perolehan nilai peserta didik kelas XI IPS 1 SMA Negeri 1 Cerme dalam mengerjakan instrumen penilaian mata pelajaran ekonomi berbasis HOTS pada uji coba pertama menunjukkan hasil kemampuan berpikir tingkat tinggi sebagai berikut; ada 5 peserta didik dalam kategori sangat baik, 8 peserta didik dalam kategori baik, 13 peserta didik dalam kategori cukup, dan 7 peserta didik dalam kategori kurang. Berikutnya dalam tenggang waktu yang tidak terlalu lama, dilakukan uji coba yang kedua dengan instumen penilaian yang sama pada uji coba pertama sehingga memperoleh hasil kemampuan berpikir tingkat tinggi sebagai berikut; ada 8 peserta didik dalam kriteria sangat baik, 3 peserta didik dalam kriteria baik, 15 peserta didik dalam kriteria cukup, dan 7 peserta didik dalam kriteria kurang. Rata-rata kemampuan berpikir tingkat tinggi peserta didik pada uji coba pertama maupun kedua tersebut berada di kategori rendah.

Ditinjau dari penelitian di atas bahwa sebagian besar peserta didik dalam berpikir tingkat tinggi masih tergolong rendah. Peserta didik memiliki kemampuan berpikir tingkat tinggi dalam memahami materi mata pelajaran serta menerapkan pada kehidupan sehari-hari. Sebagaimana penelitian dari (Noprinda \& Soleh, 2019) peserta didik mampu berpikir tingkat tinggi agar dapat menganalisis ide pokok dan menentukan fungsi dari pengetahuan yang dimiliki dalam menjawab pertanyaan. Kemudian peserta didik mampu mengevaluasi cara penyelesaian dan melakukan pengujian ulang. Serta peserta didik mampu secara kreatif menyusun penyelesaian jawaban yang benar disertai argumen dengan gaya bahasa yang efektif.

Hasil observasi yang dilakukan oleh peneliti bahwa dalam rangkaian pembelajaran Sekolah Menengah Atas (SMA) terdapat kendala yaitu latihan soal maupun instrumen penilaian yang tersedia masih kurang sesuai dengan Kurikulum 2013 Revisi 2017. Latihan soal yang tersedia maupun instrumen penilaian yang digunakan SMA Negeri 1 Gedangan terutama di kelas X IPS belum mencakup ranah kognitif menganalisis, mengevaluasi, merancang yang termasuk dalam HOTS. Peneliti juga mewawancari salah satu guru mata pelajaran ekonomi bahwasannya SMA Negeri 1 Gedangan merupakan salah satu SMA favorit di Kabupaten Sidoarjo yang beralamat di Jalan Raya Sedati KM 2 Desa Wedi Kecamatan Gedangan. Berdasarkan Surat Edaran Nomor 15 Tahun 2020 tentang Pedoman Penyelenggaraan Belajar dari Rumah dalam Masa Darurat Penyebaran Covid-19 maka kegiatan belajar antara guru dengan peserta didik melalui video confererence, teleconference, dan/atau diskusi dalam grup di media sosial atau aplikasi pesan (Kementerian Pendidikan dan Kebudayaan, 2020). Peserta didik mengerjakan latihan soal, ulangan harian, ulangan tengan semester, dan ulangan akhir semester melalui google form maupun aplikasi lainnya. Soal-soal mata pelajaran ekonomi pada latihan soal maupun instrumen penilaian tersebut masih tergolong dalam kemampuan berpikir tingkat rendah (LOTS). Soal-soal yang tersedia cenderung pada ranah kognitif mengingat, memahami, menerapkan. Hal tersebut dilakukan agar dapat memudahkan peserta didik dalam memahami materi mata pelajaran serta menghindari peserta didik untuk tidak menatap layar handphone atau laptop dalam jangka waktu yang lama. Peserta didik tidak sering dilatih dalam meningkatkan kemampuan berpikir tingkat tinggi melalui mengerjakan soal-soal dengan level kognitif HOTS.

Menurut (Mawardi et al., 2020) bahwa soal yang termasuk dalam ranah kognitif level HOTS pada Ujian Nasional tahun 2019 dengan presentase 15\%-20\% dari keseluruhan jumlah soal, lebih tinggi dibandingkan pada soal Ujian Nasional tahun 2018 dengan presentase 10\%-15\%. Peserta didik merasa kesulitan mengerjakan soal HOTS. Peserta didik memerlukan proses berpikir tingkat tinggi untuk dapat menyelesaikan 
126 Pengembangan Instrumen Penilaian Berbasis Higher Order Thinking Skills pada Mata Pelajaran Ekonomi Sekolah Menengah Atas - Ike Nur Sholiha, Riza Yonisa Kurniawan

DOI: https://doi.org/10.31004/edukatif.v4i1.1736

soal HOTS. Selain peningkatan pemahaman peserta didik terhadap materi mata pelajaran, perlu adanya penambahan waktu latihan mengerjakan soal-soal HOTS sehingga peserta didik terdorong untuk memiliki kemampuan menganalisis, mengevaluasi, dan merancang.

Berdasarkan uraian-uraian tersebut, peneliti ingin melakukan pengembangan instrumen penilaian berbasis HOTS mata pelajaran ekonomi pada kelas X Sekolah Menengah Akhir. Tujuan dari penelitan ini meliputi proses pengembangan dan kualitas dari instrumen penilaian berbasis HOTS serta mengukur kemampuan berpikir tingkat tinggi yang dimiliki oleh peserta didik. Selain itu peserta didik dapat berlatih menyelesaikan latihan soal dengan level kognitif HOTS sehingga membantu peserta didik dalam menumbuhkan pola berpikir tingkat tinggi.

\section{METODE PENELITIAN}

Jenis penelitian adalah Research and Development (R\&D). Subjek uji coba penelitian ini merupakan peserta didik kelas X IPS SMA Negeri 1 Gedangan. Jumlah keseluruhan peserta didik kelas X IPS yaitu 108 anak. Penelitian ini menerapkan metode pengembangan 3D yang merupakan modifikasi dari metode pengembangan 4D menurut Thiagarajan 1974 (Sugiyono, 2019). Dalam penelitian ini mencakup tahap Define, Design, Develop tanpa Disseminate. Prosedur penelitian diadaptasi dari (Al-Tabany, 2015) yang diterapkan oleh peneliti adalah sebagai berikut :

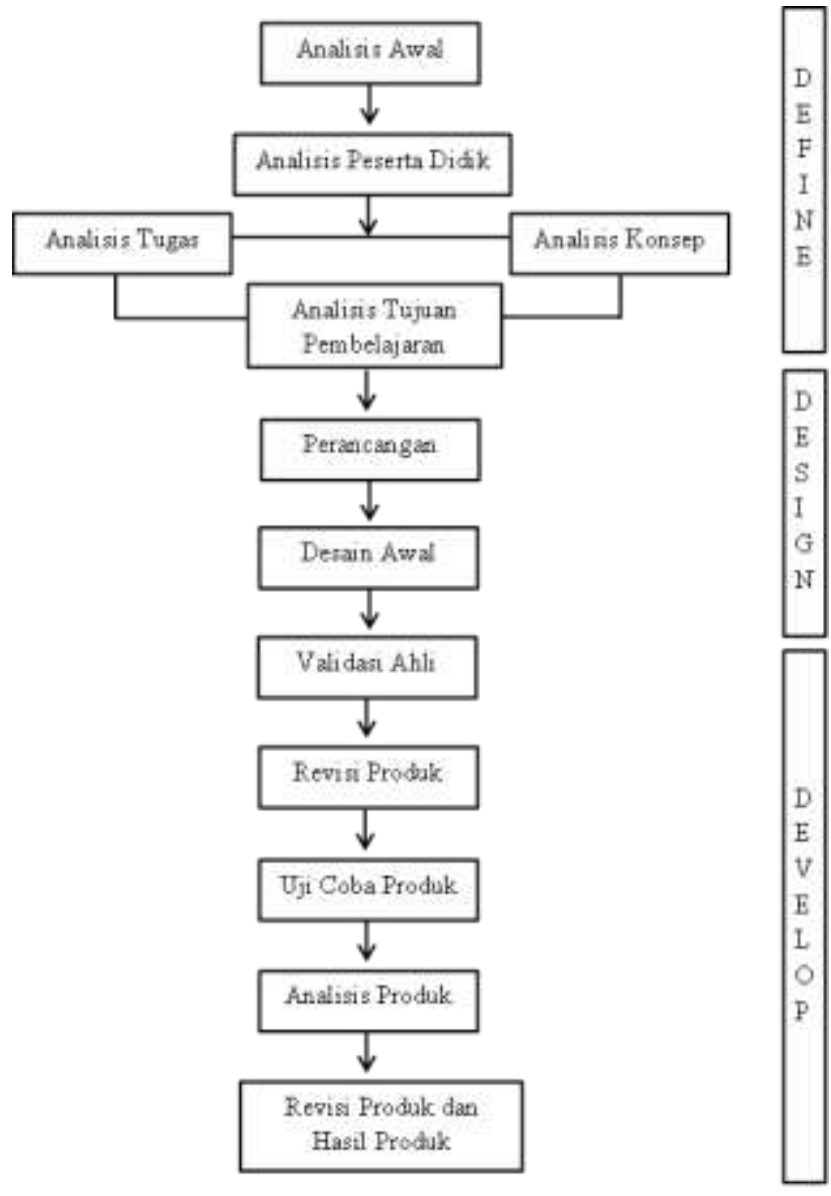

Gambar 1. Prosedur Pelaksanaan Instrumen Penilaian

Teknik analisis data dalam penelitian ini terdiri dari analisis butir soal secara kualitatif serta secara kuantitatif. Pada analisis butir soal secara kualitatif, instrumen penilaian akan divalidasi oleh ahli materi beserta ahli evaluasi. Dalam menganalisis instrumen penilaian dari keselaran materi dan segi konstruksi 
127 Pengembangan Instrumen Penilaian Berbasis Higher Order Thinking Skills pada Mata Pelajaran Ekonomi Sekolah Menengah Atas - Ike Nur Sholiha, Riza Yonisa Kurniawan

DOI: https://doi.org/10.31004/edukatif.v4i1.1736

dengan perhitungan skala Gutmann yaitu jawaban "Ya" memiliki 1 poin serta jawaban "Tidak" tidak memperoleh poin atau 0. Selanjutnya pada analisis butir soal secara kuantitatif, mengetahui hasil analisis produk seperti: a) Kevalidan atau juga kesahihan suatu tes dapat dinilai melalui ukuran (Arikunto, 2013). Kevalidan setiap butir soal ditinjau dari $\mathrm{r}$ hitung > $\mathrm{r}$ tabel melalui software Microsoft Excel; b) Tingginya tingkat kepercayaan pada hasil suatu tes, apabila hasil dari suatu tes tersebut tidak berubah atau tetap (Arikunto, 2015). Melalui software Iteman 4.3 menunjukkan reliabilitas pada melihat kolom Alpha pada tabel Reliability. Menurut (Nurhasanah, 2017) bahwa apabila suatu tes memiliki koefisien reliabel 0,200 maka termasuk kriteria sangat rendah, pada koefisien realibel 0,200-0,399 termasuk kriteria rendah, pada 0,400 0,599 tergolong kriteria cukup, pada 0,600-0,799 tergolong kriteria tinggi, serta pada 0,899-1,00 maka termasuk kriteria tinggi; c) Suatu soal dinyatakan baik apabila tingkat kesukaran soal menunjukkan proposional. Tingkat kesukaran soal mengukur besar atau kecilnya kesulitan pada soal (Arifin, 2009). Dalam menentukan tingkat kesukaran soal dengan menggunakan software Iteman 4.3 dengan melihat kolom $P$ pada Item Statistics di setiap butir soal; d) Daya pembeda tiap butir soal diketahui melalui software Iteman 4.3 dengan melihat kolom total Rpbis pada Item Statistics pada setiap butir soal; e) instrumen penilaian pada penelitian ini berupa soal pilihan ganda dengan alternatif jawaban sebanyak lima. Pada opsi jawaban terdapat jawaban yang mengecoh (distractor). Melalui software Iteman 4.3 pada kolom Prop pada tabel Option Statistics dapat mengetahui tingkat pengecoh setiap opsi jawaban. Pengecoh soal (distractor) dapat dikatakan berfungsi dengan baik apabila pengecoh soal sekurang kurangnya telah dipilih oleh 5\% peserta didik yang mengerjakan soal tersebut (Yani et al., 2014); f) Dalam menentukan kemampuan berpikir tingkat tinggi dapat diketahui melalui hasil peserta didik mengerjakan instrumen penilaian. Nilai yang diperoleh peserta didik dapat diketahui dengan menggunakan rumus menurut (Purbaningrum, 2017) berikut ini:

$$
\text { Nilai peserta didik }=\frac{\text { skor perolehan }}{\text { skor maksimal }} \times 100
$$

Gambar 2. Rumus Menghitung Nilai

\section{HASIL DAN PEMBAHASAN PENELITIAN}

\section{Proses Pengembangan Instrumen Penilaian Berbasis HOTS Mata Pelajaran Ekonomi pada Kelas X SMA.}

Penelitian pengembangan ini dilakukan pada masa pandemi Covid-19, dimana peneliti tidak melakukan tatap muka secara langsung dengan peserta didik. Instrumen penilaian yang dikembangkan dalam penelitian ini berupa soal pilihan ganda. Peserta didik mengerjakan soal pilihan ganda melalui google form. Soal pilihan ganda digunakan dalam tes tertulis dengan jumlah peserta yang sangat banyak. Penskoran dapat dilakukan dengan cepat serta soal pilihan ganda dapat meliputi materi dengan ruang lingkup yang luas, dan dapat mengukur berbagai jenis level kognitif (Penilaian Pendidikan, 2019a). Penelitian ini menerapkan metode pengembangan 3D yang merupakan modifikasi dari metode pengembangan 4D menurut Thiagarajan 1974 maka hanya mencakup tahap pendefinisian (Define), perancangan (Design), dan pengembangan (Develop).

Pada tahap pendefinisian terdiri dari beberapa langkah. Diawali dengan analisis awal, dimana peneliti melakukan observasi instrumen penilaian yang digunakan kelas X IPS di SMA Negeri 1 Gedangan. Soal-soal pada latihan soal maupun instrumen penilaian belum termasuk dalam HOTS. Peneliti melakukan wawancara dengan salah satu guru mata pelajaran ekonomi. Guru memberikan tugas kepada peserta didik seperti mengerjakan latihan soal dari guru melalui google form. Soal-soal mata pelajaran ekonomi yang terdapat pada google form tersebut masih tergolong level kognitif LOTS. Selanjutnya pada analisis peserta didik, dimana peserta didik merupakan subjek uji coba. Subjek uji coba pada penelitian pengembangan ini merupakan peserta didik kelas X IPS SMA Negeri 1 Gedangan sudah menempuh KD 3.3 peran pelaku ekonomi pada 
128 Pengembangan Instrumen Penilaian Berbasis Higher Order Thinking Skills pada Mata Pelajaran Ekonomi Sekolah Menengah Atas - Ike Nur Sholiha, Riza Yonisa Kurniawan

DOI: https://doi.org/10.31004/edukatif.v4i1.1736

kegiatan ekonomi pada semester gasal. Kelas X IPS terdiri dari kelas X IPS 1, X IPS 2, dan X IPS 3 yang masing-masing kelas berisi 36 peserta didik. Berikutnya pada analisis tugas, peneliti menentukan Kompetensi Inti (KI) dan Kompetensi Dasar (KD) pada mata pelajaran ekonomi yang akan digunakan dalam pembuatan instrumen penilaian berbasis HOTS berupa soal pilihan ganda. Kompetensi Dasar (KD) yang akan digunakan dalam pembuatan soal HOTS adalah KD 3.3 yakni menganalisis peran pelaku ekonomi dalam kegiatan ekonomi. Langkah pertama pada panduan penulisan soal berbasis HOTS yaitu menentukan kompetensi dasar dan materi yang akan dinilai (Penilaian Pendidikan, 2019b). Dalam penyusuanan instrumen penilaian memperhatikan Kompetensi Inti (KI) dan Kompetensi Dasar (KD) dalam silabus SMA mata pelajaran ekonomi kelas X. Berikut KD dan indikator pencapaian pembelajaran:

Tabel 1. Rumusan Kompetensi Dasar dan Indikator

\begin{tabular}{|c|c|}
\hline Kompetensi Dasar & Indikator \\
\hline $\begin{array}{l}\text { - } \text { Menganalisis peran } \\
\text { pelaku ekonomi } \\
\text { dalam kegiatan } \\
\text { ekonomi }\end{array}$ & $\begin{array}{l}\text { Kegiatan Ekonomi } \\
\text { - Produksi (Pengertian produksi, faktor-faktor produksi, teori } \\
\text { perilaku produsen, konsep biaya produksi, konsep penerimaan, } \\
\text { dan laba maksimum) } \\
\text { - } \text { Distribusi (Pengertian distribusi, faktor-faktor yang } \\
\text { memengaruhi distribusi, mata rantai distribusi) } \\
\text { - Konsumsi (Pengertian konsumsi, tujuan konsumsi, faktor- } \\
\text { faktor yang memengaruhi konsumsi, teori perilaku konsumen) } \\
\text { Pelaku Ekonomi } \\
\text { - Pelaku-pelaku ekonomi: Rumah Tangga Konsumsi } \\
\text { (konsumen), Rumah Tangga Produksi (produsen), Pemerintah, } \\
\text { dan Masyarakat Luar Negeri } \\
\text { - Peran pelaku ekonomi } \\
\text { - Model diagram interaksi antarpelaku ekonomi (circular flow } \\
\text { diagram) sederhana (dua sektor), tiga sektor, dan empat sector }\end{array}$ \\
\hline
\end{tabular}

Kemudian pada analisis konsep, materi pada Kompetensi Dasar (KD) yang sudah ditentukan berikutnya dikembangkan menjadi instrumen penilaian kelas X sebanyak 20 butir soal pilihan ganda dengan alternatif jawaban sebanyak lima. Berlanjut pada analisis tujuan pembelajaran, sesuai dengan indikator pada Kompetensi Dasar (KD) serta dapat melatih peserta didik berpikir tingkat tinggi.

Pada tahap perancangan terdapat penyusunan tes acuan patokan dan desain awal. Dalam penyusunan tes acuan patokan, terlebih dahulu menyusun kisi-kisi setiap butir soal yang akan dikembangkan menjadi soalsoal HOTS. Berdasarkan panduan penulisan soal berbasis HOTS, langkah kedua ialah menyusun kisi-kisi dan langkah ketiga yaitu merumuskan indikator soal yang mencakup prinsip penyusunan soal HOTS seperti terdapat stimulus (Penilaian Pendidikan, 2019b). Stimulus yang bersifat positif dan tergolong berita terkini sehingga dapat menarik minat membaca peserta didik, selain mendorong peserta didik dapat berpikir tingkat tinggi juga dapat menambah wawasan. Contoh stimulus pada soal sebagai berikut:

Tabel 2. Contoh Stimulus pada Soal

\begin{tabular}{ll}
\hline \multicolumn{1}{c}{ Indikator Soal } & \multicolumn{1}{c}{ Soal } \\
\hline Disajikan pernyataan & Bu Lilik memiliki kompor listrik dan kompor gas. Dia biasanya \\
tentang kegiatan & menggunakan kompor listrik untuk memasak di rumah. Di tengah \\
konsumsi. Peserta didik & pandemi Covid-19 saat ini, bekerja dan aktivitas pembelajaran \\
dapat menganalisis & dilakukan dari rumah. Hal tersebut menyebabkan keluhan kenaikan \\
faktor-faktor yang & tagihan listrik dirasakan oleh Bu Lilik. Untuk mengatasi keluhan \\
mempengaruhi & tersebut, dia beralih menggunakan kompor gas. Bu Lilik mengeluarkan \\
konsumsi barang. & dana sebesar Rp 250.000,00 ketika menggunakan kompor listrik setiap \\
\hline
\end{tabular}


bulan. Namun dia dapat menghemat pengeluaran menjadi $\mathrm{Rp}$

$150.000,00$ setiap bulan jika menggunakan kompor gas.

Berdasarkan ilustrasi di atas, faktor yang mempengaruhi konsumsi

kompor adalah....

a. Pendapatan

b. Selera

c. Adat istiadat

d. Ketersediaan barang

e. Harga barang substitusi

Berikutnya dalam desain awal, merancang desain sampul instrumen penilaian beserta petunjuk pengerjaan. Kemudian merangkai soal sesuai dengan tahapan penyusunan soal bentuk pilihan ganda. Penyusunan setiap butir pertanyaan sesuai dengan kisi-kisi soal serta sesuai dengan kaidah penulisan soal HOTS. Langkah selanjutnya, pembuatan pedoman penskoran soal pilihan ganda.

Pada tahap pengembangan juga terdiri dari beberapa langkah. Langkah berikutnya yang ditempuh setelah pembuatan soal pilihan ganda berbasis HOTS telah selesai yaitu penilaian dari berbagai ahli terkait penyusunan instrumen penilaian. Ahli materi terkait keselarasan materi mata pelajaran ekonomi kelas $\mathrm{X}$ semester gasal dengan KD 3.3 yang terdapat dalam soal pilihan ganda berbasis HOTS tersebut. Ahli evaluasi terkait tingkat kualitas soal pilihan ganda berbasis HOTS dari segi konstruksi. Berikutnya melakukan perbaikan pada soal pilihan ganda berdasarkan dengan saran dan kritik dari validasi ahli. Setelah instrumen penilaian melalui langkah perbaikan soal maka instrumen penilaian dapat diujikan kepada seluruh peserta didik X IPS. Selanjutnya instrumen penilaian masuk dalam tahap analisis produk seperti uji validitas, uji reliabilitas, menguji tingkat kesukaran soal, daya pembeda soal, dan pengecoh soal. Berdasarkan hasil peserta didik mengerjakan instrumen penilaian maka diperoleh informasi mengenai kemampuan berpikir tingkat tinggi. Langkah terakhir pada instrumen penilaian yaitu dilakukan perbaikan soal lalu menghasilkan beberapa butir soal yang merupakan hasil produk pengembangan yang layak digunakan dalam pembelajaran.

\section{Kelayakan Instrumen Penilaian Berbasis HOTS Mata Pelajaran Ekonomi pada Kelas X SMA Kelayakan kualitatif}

Dalam mengetahui kelayakan instrumen penilaian berbasis HOTS dengan melalui penilaian dari berbagai ahli terkait penyusunan instrumen penilaian. Penilaian lembar validasi berpedoman pada modul menurut (Widana, 2017). Pada komponen kualitas materi mendapat presentase sebesar $82,5 \%$ dan termasuk dalam kriteria sangat kuat. Selanjutnya pada komponen kualitas evaluasi memiliki presentase sebesar 90\% serta masuk dalam kriteria sangat kuat. Berdasarkan kriteria menurut (Riduwan, 2016) instrumen penilaian berbasis HOTS yang dikembangkan dapat dikatakan sangat kuat, bilamana presentase semua komponen dalam lembar validasi sebesar $81 \%-100 \%$. Instrumen penilaian diperbaiki sesuai dengan saran dan kritik dari validasi ahli.

\section{Kelayakan kuantitatif}

Berikutnya instrumen penilaian memasuki tahap analisis produk melalui software Microsoft Excel dan Iteman 4.3. Diketahui $\mathrm{r}$ tabel dari 134 peserta didik yaitu 0.189. Hasil analisis validitas soal diperoleh sebanyak 18 butir soal dinyatakan valid, lalu sebanyak 2 butir soal dinyatakan tidak valid. Pada instrumen penilaian butir soal yang dinyatakan tidak valid terletak pada nomor 2 dan 20.

Dalam menentukan reliabilitas, terlihat pada kolom Alpha menunjukkan koefisien reliabel sebesar 0,680. Maka reliabilitas instrumen penilaian berbasis HOTS ini termasuk dalam kriteria tinggi. Berdasarkan hasil analisis, instrumen penilaian ini memiliki paling banyak tingkat kesukaran soal berkriteria sedang dengan jumlah 13 butir soal (65\%) serta 5 soal (25\%) kategori sukar dan 2 soal (10\%) kategori mudah. 
130 Pengembangan Instrumen Penilaian Berbasis Higher Order Thinking Skills pada Mata Pelajaran Ekonomi Sekolah Menengah Atas - Ike Nur Sholiha, Riza Yonisa Kurniawan

DOI: https://doi.org/10.31004/edukatif.v4i1.1736

Sebagaimana penelitian (Maulidia \& Pahlevi, 2020) dengan judul "Pengembangan Instrumen Penilaian Tes Soal Pilihan Ganda Berbasis HOTS pada Mata Pelajaran Administrasi Umum Jurusan OTKP SMKN 1 Lamongan" bahwa rata-rata tingkat kesukaran butir soal pada instrumen penilaian tersebut yaitu berkategori sedang dengan jumlah 22 butir soal (74\%). Dengan tingkat kesukaran yang beragam tingkat proposional antara soal dengan kriteria sukar, sedang, mudah maka dapat memilah antara peserta didik yang memiliki kemampuan baik maupun kurang (Fitrianawati, 2015). Berdasarkan hasil analisis daya pembeda soal menunjukkan paling banyak berkriteria sedang dengan 9 soal (45\%) serta 6 soal (30\%) kriteria baik dan 5 soal (25\%) kriteria cukup baik. Keseluruhan pengecoh yang terdapat pada setiap butir soal telah berfungsi dengan baik. Distraktor dapat mengecoh peserta didik, dimana terdapat peserta didik memilih pilihan jawaban yang salah.

\section{Kemampuan Berpikir Tingkat Tinggi Peserta Didik Dinilai dari Hasil Pengerjaan Instrumen Penilaian Berbasis HOTS Mata Pelajaran Ekonomi}

Menurut (Purbaningrum, 2017) dalam mengukur kemampuan berpikir tingkat tinggi dapat dengan memberikan tes berbasis HOTS kepada peserta didik. Hasil jawaban peserta didik dinilai oleh peneliti. Nilai hasil tes setiap peserta didik kemudian dikelompokkan sesuai dengan kriteria. Berikut presentase kemampuan berpikir tingkat tinggi peserta didik kelas X IPS:

Tabel 2. Presentase HOTS peserta didik kelas X IPS

\begin{tabular}{ccc}
\hline Frekuensi & Presentase & Kriteria \\
\hline 1 & $1 \%$ & Sangat Baik \\
\hline 9 & $8 \%$ & Baik \\
\hline 30 & $28 \%$ & Cukup \\
\hline 46 & $43 \%$ & Kurang \\
\hline 22 & $20 \%$ & Sangat Kurang \\
\hline
\end{tabular}

Berdasarkan tabel nilai dari jumlah keseluruhan 108 peserta didik dalam mengerjakan 20 butir soal pilihan ganda berbasis HOTS maka diperoleh rata-rata peserta didik kelas X IPS memiliki kemampuan berpikir tingkat tinggi berkriteria kurang. Sebagaimana penelitian (Herliana \& Kurniawan, 2021) berjudul "Pengembangan Instrumen Penilaian Berbasis HOTS pada Mata Pelajaran Ekonomi" menunjukkan bahwa rata-rata peserta didik kelas XI IPS memiliki pola berpikir tingkat tinggi yang masih tergolong dalam kriteria kurang di SMA Negeri 1 Sooko. Terdapat sebanyak 78 peserta didik dari 134 peserta didik keseluruhan yang temasuk dalam kriteria kurang.

\section{KESIMPULAN}

Dalam pembuatan instrumen penilaian berbasis HOTS berupa soal pilihan ganda, Kompetensi Dasar (KD) semester gasal kelas X digunakan yaitu KD 3.3 yakni menganalisis peran pelaku ekonomi dalam kegiatan ekonomi. Pengembangan instrumen penilaian berbasis HOTS ini menghasilkan 18 butir soal terbaik. Reliabilitas instrumen penilaian berbasis HOTS ini termasuk dalam kriteria tinggi. Instrumen penilaian ini memiliki paling banyak tingkat kesukaran soal berkriteria sedang serta daya pembeda soal menunjukkan paling banyak berkriteria sedang. Keseluruhan pengecoh yang terdapat pada setiap butir soal telah berfungsi dengan baik. Namun berdasarkan hasil penelitian ini menunjukkan bahwa rata-rata kemampuan berpikir tingkat tinggi yang dimiliki oleh peserta didik kelas X IPS SMA Negeri 1 Gedangan termasuk dalam kriteria kurang. Maka adanya peningkatan kemampuan berpikir tingkat tinggi peserta didik melalui kegiatan pembelajaran, mengembangkan ranah kognitif HOTS dalam latihan soal dan instrumen penilaian. Peserta didik dapat dilatih menuangkan pendapat yang lebih luas dalam menyelesaikan suatu permasalahan pada soal. 
131 Pengembangan Instrumen Penilaian Berbasis Higher Order Thinking Skills pada Mata Pelajaran Ekonomi Sekolah Menengah Atas - Ike Nur Sholiha, Riza Yonisa Kurniawan

DOI: https://doi.org/10.31004/edukatif.v4i1.1736

\section{DAFTAR PUSTAKA}

Abosalem, Y. (2016). Assessment Techniques And Students' Higher-Order Thinking Skills. ICSIT 2018 - 9th International Conference On Society And Information Technologies, Proceedings, 4(1), 61-66. Https://Doi.Org/10.11648/J.Ijsedu.20160401.11

Akmala, N. F., Suana, W., \& Sesunan, F. (2019). Analisis Kemampuan Berpikir Tingkat Tinggi Siswa SMA Pada Materi Hukum Newton Tentang Gerak. Titian Ilmu: Jurnal Ilmiah Multi Sciences, 11(2), 67-72. Https://Doi.Org/10.30599/Jti.V11i2.472

Al-Tabany, T. I. B. (2015). Mendesain Model Pembelajaran Inovatif, Progresif, Dan Kontekstual: Konsep, Landasan, Dan Implementasinya Pada Kurikulum 2013 (Kurikulum Tematik/KTI). Prenadamedia Group.

Anggraena, Y. (2019). Pengembangan Kurikulum Matematika Untuk Meningkatkan Kemampuan Siswa Dalam Penalaran Dan Pemecahan Masalah. Alifmatika: Jurnal Pendidikan Dan Pembelajaran Matematika, 1(1), 15-27. Https://Doi.Org/10.35316/Alifmatika.2019.V1i1.15-27

Anwar, M. (2015). Filsafat Pendidikan. Kencana.

Arifin, Z. (2009). Evaluasi Pembelajaran. PT Remaja Rosdakarya Offset.

Arikunto, S. (2013). Dasar-Dasar Evaluasi Pendidikan. PT Bumi Aksara.

Arikunto, S. (2015). Dasar-Dasar Evaluasi Pendidikan. PT Bumi Aksara.

Arnyana, I. B. P. (2019). Pembelajaran Untuk Meningkatkan Kompetensi 4C (Communication, Collaboration, Critical Thinking, Dan Creative Thinking) Untuk Menyongsong Era Abad 21. Prosiding: Konferensi Nasional Matematika Dan IPA Universitas PGRI Banyuwangi, 1.

Darise, G. N. (2019). Implementasi Kurikulum 2013 Revisi Sebagai Solusi Alternatif Pendidikan Di Indonesia Dalam Menghadapi Revolusi Industri 4.0. Jurnal Ilmiah Iqra', 13(2), 41. Https://Doi.Org/10.30984/Jii.V13i2.967

Fanani, M. Z. (2018). Strategi Pengembangan Soal Hots Pada Kurikulum 2013. Edudeena, 2(1), 57-76. Https://Doi.Org/10.30762/Ed.V2i1.582

Fitrianawati, M. (2015). Peran Analisis Butir Soal Guna Meningkatkan Kualitas Butir Soal, Kompetensi Guru Dan Hasil Belajar Peserta Didik. Prosiding Seminar Nasional Pendidikan PGSD UMS \& HDPGSDI Wilayah Jawa, 5(3), 282-295. ISBN 978-602-70471-2-9 PERAN. Http://Hdl.Handle.Net/11617/9117

Herliana, O., \& Kurniawan, R. Y. (2021). Pengembangan Instrumen Penilaian Berbasis Hots Pada Mata Pelajaran Ekonomi. Jurnal Pendidikan Ekonomi, 6(1), 47-51.

Kementerian Pendidikan Dan Kebudayaan. (2020). Surat Edaran Nomor 15 Tahun 2O2O Pedoman Penyelenggaraan Belajar Dari Rumah Dalam Masa Darurat Penyebaran Corona Virus Disease (Covid19). In Kementerian Pendidikan Dan Kebudayaan (Issue 021). Kementerian Pendidikan Dan Kebudayaan.

Kurniawan, R. Y., \& Lestari, D. (2019). The Development Assessment Instruments Of Higher Order Thinking Skills On Economic Subject. Dinamika Pendidikan, 14(1), 102-115. Https://Doi.Org/10.15294/Dp.V14i1.19226

Maulidia, F., \& Pahlevi, T. (2020). Pengembangan Instrumen Penilaian Tes Soal Pilihan Ganda Berbasis HOTS Pada Mata Pelajaran Administrasi Umum Jurusan OTKP SMK Negeri 1 Lamongan. Jurnal $\begin{array}{llll}\text { Pendidikan Administrasi } \quad \text { Perkantoran } & \text { (JPAP), } & \text { 8(1), }\end{array}$ Https://Journal.Unesa.Ac.Id/Index.Php/Jpap/Article/View/8114

Mawardi, A. V., Yanti, A. W., \& Arrifadah, Y. (2020). Analisis Proses Berpikir Siswa Dalam Menyelesaikan Soal HOTS Ditinjau Dari Gaya Kognitif. Jurnal Review Pembelajaran Matematika, 5(1), 40-52. Https://Doi.Org/10.15642/Jrpm.2020.5.1.40-52

Noprinda, C. T., \& Soleh, S. M. (2019). Pengembangan Lembar Kerja Peserta Didik (LKPD) Berbasis Higher Order Thinking Skill (HOTS). Indonesian Journal Of Science And Mathematics Education, 2(2), 168- 
132 Pengembangan Instrumen Penilaian Berbasis Higher Order Thinking Skills pada Mata Pelajaran Ekonomi Sekolah Menengah Atas - Ike Nur Sholiha, Riza Yonisa Kurniawan

DOI: https://doi.org/10.31004/edukatif.v4i1.1736

176. Https://Doi.Org/10.24042/Ijsme.V2i2.4342

Nurhasanah, S. (2017). Pratikum Statistika 2. Salemba Empat.

Nursalam, Angriani, A. D., Darmawati, Baharuddin, \& Aminuddin. (2018). Developing Test Instruments For Measurement Of Students' High-Order Thinking Skill On Mathematics In Junior High School In Makassar. Journal Of Physics: Conference Series, 1028(1). Https://Doi.Org/10.1088/17426596/1028/1/012169

Penilaian Pendidikan, T. P. (2019a). Panduan Penilaian Tes Tertulis. In Pusat Penilaian Pendidikan. Pusat Penilaian Pendidikan.

Penilaian Pendidikan, T. P. (2019b). Panduan Penulisan Soal HOTS. In Pusat Penilaian Pendidikan. Pusat Penilaian Pendidikan.

Purbaningrum, K. A. (2017). Kemampuan Berpikir Tingkat Tinggi Siswa Smp Dalam Pemecahan Masalah Matematika Ditinjau Dari Gaya Belajar. Jurnal Penelitian Dan Pembelajaran Matematika, 10(2), 40-49. Https://Doi.Org/10.30870/Jppm.V10i2.2029

Riduwan. (2016). Skala Pengukuran Variabel-Variabel Penelitian. Alfabeta.

Sugiyono. (2019). Metode Penelitian Kuantitatif, Kualitatif, Dan R\&D. CV Alfabeta.

Widana, I. W. (2017). Modul Penyusunan Soal Higher Ordher Thinking Skill (HOTS). In Direktorat Pembinaan SMA Direktorat Jenderal Pendidikan Dasar Dan Menengah Kementerian Pendidikan Dan Kebudayaan (Vol. 53, Issue 9). Direktorat Pembinaan SMA Direktorat Jenderal Pendidikan Dasar Dan Menengah Kementerian Pendidikan Dan Kebudayaan.

Yani, A., Asri, A. F., \& Burhan, A. (2014). Analisis Tingkat Kesukaran, Daya Pembeda Dan Fungsi Distraktor Soal Ujian Semester Ganjil Mata Pelajaran Produktif Di SMK Negeri 1 Indralaya Utara Tahun Pelajaran 2012/2013. Jurnal Pendidikan Teknik Mesin, 1(2), 98-115. 